REZENSIONEN

\section{Disability Studies and the Discourse on Enhancement}

\author{
M. Eilers, Chr. Rehmann-Sutter, K. \\ Grüber (eds.): Verbesserte Körper - \\ gutes Leben? Bioethik, Enhancement \\ und die Disability Studies. Frankfurt
} a. M. et al.: Peter Lang, 2012, 331 p., ISBN 978-363-163-0655, Euro 56,95

\section{Review by Gregor Wolbring, University of Calgary, Canada ${ }^{1}$}

When I was asked to review the book, I was excited because there is a need to explicitly outline the enhancement discourse through a disability studies lens and especially to show the utility of disability studies analysis for other academic fields. On the other hand, it is also important to show the impact of arguments used in the enhancement discourse of other academic fields and, for that matter, outside the academic discourse on the arguments used in disability studies and on the lifes of disabled people. ${ }^{2}$ Although literature covering the topic of enhancement through a disability studies lens has existed for some time, the amount of literature is much less than the literature around ethical issues linked to enhancement themes.

\section{Overview}

The German-language book has four sections: Leitbegriffe, Behinderung als Erfahrungsraum, Normativität and Ethik von Enhancement [Key Concepts, Disability as a Space of Experience, Normativity, and Ethics of Enhancement].

Section one covers issues such as the problem of technology assessment that focusses on futuristic claims of envisioned technologies and their impact on society at the expense of discussing the here and now of what leads to the demand (Alfred Nordman); the meaning of a good life and human nature, where Christina Schües, among others, concludes that "die Hierarchisierung von Eigenschaftszuschreibungen oder eine angenommene Zentralität von einer menschlichen Natur nicht die Grundlage für ethische Entscheidungen sein kann" (p. 58) [the hierarchization of assigned properties or an assumed centrality of human nature cannot be the basis for ethical decisions]. Christoph Rehmann-Sutter put forward the view that the desire for enhancement can be better discussed within the framework of a good life than an ethics of rights and duty: "Man kann das Wünschbare an den Enhancement-Biotechnologien im Kontext einer Ethik des guten Lebens besser diskutieren als in einer Ethik der Rechte und Pflichten" (p. 63), and that disability studies must be included in this philosophical discussion of the desirability of enhancement in bioethics: "Dass es für diese philosophische Klärung der Wünschbarkeit von Enhancement in der Bioethik heute unverzichtbar ist, die Disability Studies einzubeziehen, ist der zweite Teil der These." (p. 64)

Section two covers "Bedingungen für ein gutes Leben mit Behinderung" [Conditions for a good life with a disability] (Katrin Grüber); "Lehren aus der Geschichte des Cochlea-Implantats" [Lessons from the history of the Cochlear implant] (Stuart Blume); "Konstruktion und Dekonstruktion von Gehörlosigkeit bei Kindern" [Construction and deconstruction of deafness in children] (Sigrid Bosteels and Stuart Blume).

Section three is about "Embodiment, Enhancement und Normativität" [Embodiment, enhancement and normativity] (Jackie Leach Scully); "Normative und selektive Implikationen der Prothetik nach dem Ersten Weltkrieg" [Normative and selective implications of prosthetics after the First World War] (Miriam Eilers); "Posthumane Verkörperungen in einer Post-Gender Welt? Kulturelle Dimensionen der kosmetischen Chirurgie" [Posthumane embodiments in a postgender world? Cultural dimensions of cosmetic surgery] (Birgid Stammberger), and a discussion of what is an "impairment or enhancement" discussion. In particular, Trijsje Franssen critically discusses the concept of enhancement proposed by the ethicist John Harris, which defines disability as an unwanted and injured condition, trying not to refer to the "normal".

Section four is described as trying to generate key concepts (Leitbegriffe) which could be useful for the ethical discussion of enhancement. The articles cover "Stimmungs-Enhancement" [Mood enhancement] (Lisa Forsberg), "Die ethi- 
sche Relevanz von Körperbildern für die Enhancement-Debatte" [Ethical relevance of body images for the enhancement debate] (Annika den Dikken), "Alternde Gesellschaft und kognitives Enhancement" [Aging society and cognitive enhancement] (Morten Hillgaard Bülow), "Eine Kritik am Transhumanismus" [A criticism of transhumanism] (Nicolai Münch), and "Nootropika, Smart Drugs und das Problem der Governance" [Nootropics, smart drugs and the problem of governance] (Natasha Burns).

All articles have interesting thoughts and should trigger good discussions within a reader and among readers. All articles give also food for thought to disability studies scholars. However, of particular interest to disability studies scholars should be Trijsje Franssen's article due to her rebuttal of John Harris' line of arguments which adds to the rebuttal by others from the disability studies field. Christina Schües' article should be of particular interest to the eco-ability scholars (e.g. Nocella et al. $2012^{3}$ ) and covers the intersection of disabled people with animals and the environment. Miriam Eilers' article should be of particular interest to people working on bionics as well as on ability expectations as the article links the utility of body modifications to ability expectations of society (e.g. productivity) which per se are not linked to a normative understanding of health/impairment.

\section{Some Problems...}

However, from a disability studies perspective this book also has some serious flaws. In the introduction of the book one reads the following: "Dieses Buch geht davon aus, dass die Debatte über die Ethik verbessernder biotechnologischer Eingriffe in den menschlichen Körper ('human enhancement') durch den systematischen Einbezug der Perspektive und der Erfahrungen von Menschen mit Behinderungen konkreter wird, Grund gewinnt und inhaltlich bereichert wird. Zudem möchte es den Zusammenhang zwischen den Themenbereichen Enhancement und Disability Studies genauer erklären. Mit der These aus den Disability Studies, dass biomedizinische Interventionen ambivalent für Menschen mit Behinderungen sind, und dass zum Verständnis dieser Ambivalenz Erfahrungen von Betroffenen nötig sind, wird die ethische Sen- sibilität verfeinert, die nötig ist, um zur Ethik von Enhancement umsichtig Stellung zu nehmen." (p. 9) [This book assumes that the debate on the ethics of human enhancement through biotechnology will become more concrete, gain ground and be enriched by systematically including the perspective and experiences of people with disabilities. It also aims to explain in more detail the relation between the topics of enhancement and disability studies. The thesis of the disability studies that biomedical interventions are ambivalent for people with disabilities and that it is necessary to include the experiences of those affected in order to understand this ambivalence leads to a refined ethical sensibility which is needed to give a cautious opinion on the ethics of enhancement.]

The problem of coverage of "disability studies": One of the problems of the book is its use and coverage of the term disability studies. Nowhere is it made clear that disability studies is an academic field of inquiry. It also confuses terminology. There is no medical model of disability studies or social model of disability studies. What the authors mean, I assume, is medical model of disability or social model of disability.

The problem of the coverage of identity: The issue of identity is one main aspect of inquiry by disability studies scholars. Identity is also covered intensively in various book chapters (e.g. pp. 98102). Katrin Grüber writes for example: "Der Prozess der Identitätsbildung wird stark von der Fremdwahrnehmung, d. h. auch von gesellschaftlichen Vorstellungen beeinflusst" (p. 99) [The process of identity formation is strongly influenced by the perception by others, i.e. also by social expectations] and "Deshalb wird es Menschen mit Behinderungen erschwert, sich selbst positiv zu definieren" (p. 99) [This makes it difficult for people with disabilities to define themselves positively].

Given that the problem of disabled people of being able to define themselves in a positive way especially due to the influence of societies views on the matter, it is rather puzzling that the editors take up in the introduction chapter without critical reflection a definition of identity that is based on a negative understanding of one's ability-diverse body by promoting the WHO definition of disability. Although the WHO definition allows for the identification of some so- 
cial factors as disabling parameters, it demands a body identity that is based in a deficiency model. As such it does not allow one to identify oneself in a positive way. Jackie Scully talks about variant bodies, but the WHO document highlighted is not about variant but deviant bodies.

It is also puzzling that the introduction characterizes the difficulties of hearing parents to be part of the non-hearing community as discrimination of the non-disabled. This dynamic of "reverse discrimination" is much more complicated, and a lot of literature exists around identity and phases that lead to exclusion of others. This "reverse discrimination" plays itself out in quota systems around employment.

Finally, it is not clear what the purpose is of the statement: "Aber es ist nicht unwahrscheinlich, dass erheblich größere Inklusionsprobleme gegenüber denjenigen auftreten können, die über biotechnisch gesteigerte Funktionsfähigkeiten verfügen." (p. 11) [But it is not unlikely that much greater problems of inclusion may arise as compared to those with biotechnologically enhanced abilities.]

It is well known that people who stick out on the other end of the ability scales often also have to deal with discrimination (gifted kids...). This discrimination only decreases once a certain amount of people have the same ability or if the ability is seen as so useful for the purpose of other ability expectations that one accepts that "weird" ability. Indeed, one could make the point that the existence of normative ability expectations intrinsic to the negative view of a person lacking certain abilities (as evident in the here promoted WHO definition) leads to the position. Many who believe in enhancement see less abilities as impairments and build an identity around the enhancement. Gregory Stock stated many years ago that eventually there will be classes based on certain levels of abilities that do not relate to each other anymore and in the case of genetics might indeed become species that are genetically incompatible.

\section{The Coverage of Enhancement}

A second set of problems is the scope of enhancement covered. The book discusses whether one can draw a line between therapeutic enhancement and non-therapeutic enhancement and, in general, between therapy and enhancement, concluding that the line cannot be drawn. But the book is not clear what the consequences are for people labelled as impaired. The book also does not engage with the many different forms of enhancement (independent of whether they are labelled as therapeutic or not), such as permanent enhancements, transient enhancements, genetic-based enhancements, drug-based enhancements, hardware-based enhancements, enhancements through non-invasive means, enhancements through invasive means, enhancement interventions taking place on different levels of biological development, all of which are debated differently with different impacts on the ability of disabled people (people who are already labelled as impaired) to self-identify in a positive way and on their well-being.

From a disability studies perspective, different enhancement enabling products have different impacts on morphology- and ability-diverse people. To debate whether one can make a distinction between therapy and enhancement is a red herring discussion. In the end, it is about the question "why do we want enhancements?". Indeed some book chapters question the narratives around some of the whys. Interestingly, the why of ability expectation of the person, the why of ableism (a term used by the disabled people's rights movement since the 1970s), is not covered; as is not the constant creep in ability expectations that look for "improvements" of what humans can do based on nonbody-related ability expectations. Indeed the fairly new field of ability studies investigates the why not only within the framework of the body and disability studies but beyond. It asks questions such as why are certain abilities expected? Why are certain abilities privileged and which abilities are expected and how are ability expectations used? This change in ability expectations can be achieved through genetic and other biological means, but it also is evident in the use of non-biological devices such as brain-machine interfaces and social robots, which all lead to a change in ability expectations which pose a problem for disabled people.

It is also troubling when the authors move enhancement automatically into a medical narrative: "Man könnte z. B. einfach von 'verändernden' Technologien sprechen. Damit wären medizinische Eingriffe gemeint, die nicht dazu gedacht sind zu heilen, was krank ist, sondern den 
gegebenen Status des Körpers zu verändern.” (p. 13) [One could. e.g. simply speak of "modifying" technologies. This would mean medical interventions which are not intended to cure what is ill, but to modify the given state of the body.] If it is a medical intervention, it has to be linked to a normative narrative around health, thereby changing the meaning of health to include such enhancements leading to an enhancement version of health.

From a disability studies perspective, it is also problematic to say: "Wie die Anwendung von Enhancementtechnologien das tägliche Leben beeinflussen würde, ist zudem, wenn man von einzelnen Beispielen absieht, heute noch kaum vorstellbar." (p. 14) [How the application of enhancement technologies would influence daily life is - apart from a few examples - still hardly conceivable.]

It is well known how ability enhancements impact daily life. We have the constant examples of hardware used to enhance abilities of the human body. We might not know how some of the more down the road enhancements such as using synthetic biology and the artificial womb to really design genomes and grow humans or immortality or cyborgs as sentient beings might play themselves out. However, this sentence falls into the very trap Alfred Nordman warns about in his contribution. From a disability studies perspective one does not have to envision the daily life under immortality and designer genomes to understand how ability enhancements play themselves out today. Indeed, the fields of disability studies among others address the daily life consequences of ability judgments and ability expectations and how ability expectations influence scientific and technological developments and vice versa and the interactions between humans.

\section{Conclusion}

Although there are many interesting and illuminating articles in the book which are worth reading, I posit that it fails its own stated purpose. The reader does not learn about the academic field of disability studies and the reader does not gain a solid overview of what disability studies scholars say about enhancements and the different impacts different forms of enhancement have on ability-diverse people who are labelled as impaired. Although there are some interesting articles in the book, it misses to mention many thoughts on enhancement from a disability studies perspective which has existed for over 15 years at least. This overview of the arguments could have been dealt with within the introduction, for example. It also failed to make it easier for ability-diverse people labelled as impaired to self-identify in a positive way, given that the introduction of the books biases the reader toward a deficiency narrative. As such, the book is more useful for people who already are knowledgeable in disability studies and the enhancement discourse to read about what some colleagues think than to illuminate people who do not already know the disability studies discourse.

\section{Notes}

1) The review of this book is performed through the lens of the academic field of disability studies. The reviewer has an appointment as Associate Professor in Community Rehabilitation and Disability Studies, University of Calgary, Alberta, Canada and is a Visiting Professor of Ability Expectation and Ableism Studies (short Ability Studies) at American University of Sovereign Nations (AUSN), Arizona, USA. He has worked for more than 15 years on various aspects of enhancement.

2) The reviewer uses the term disabled people because it is the one term used in the literature. The reviewer could also have used the term "people with disabilities". The book uses both versions "Menschen mit Behinderungen" und "behinderte Menschen". However, whether one uses disabled people or people with disabilities both terms themselves are unclear as they cover two aspects. One aspect is that a person experiences a disability/disablement (disablism); this can originate within the body (medical model of disability) or the environment (social model of disability). The second aspect is that it is used to describe the body. Here, there are also two options: one can follow the medical model of body identity, where disability is used synonymously with terms such as impairment, deviant, deficient, not normal. But one could also follow the social model of body identity, where the body can be seen as ability-diverse, as variant, as a different form of being (Deaf culture is one narrative where this selfunderstanding of the body is evident).

3) Nocella II, A.J.; Duncan, J.M.; Bentley, J.K.C. (eds.), 2012: Earth, Animal, and Disability Liberation: The Rise of the Eco-Ability Movement. New York 